\title{
Drinking-Water Supply for CKDu Affected Areas of Sri Lanka, Using Nanofiltration Membrane Technology: From Laboratory to Practice
}

\author{
Titus Cooray ${ }^{1,2,3,4}$, , Yuansong Wei ${ }^{1,2,3, *} \mathbb{C}$, Junya Zhang ${ }^{1,2}$, Libing Zheng ${ }^{1,2}$, Hui Zhong ${ }^{1,2}$, \\ Sujithra K. Weragoda ${ }^{5}$ and Rohan Weerasooriya ${ }^{6}$ \\ 1 State Key Joint Laboratory of Environmental Simulation and Pollution Control, Research Center for \\ Eco-Environmental Sciences, Chinese Academy of Sciences, Beijing 100085, China; titus@uwu.ac.lk (T.C.); \\ jyzhang@rcees.ac.cn (J.Z.); lbzheng@rcees.ac.cn (L.Z.); zhonghui1977@163.com (H.Z.) \\ 2 Department of Water Pollution Control Technology, Research Center for Eco-Environmental Sciences, \\ Chinese Academy of Sciences, Beijing 100085, China \\ 3 University of Chinese Academy of Sciences, Beijing 100049, China \\ 4 Department of Science and Technology, Uva Wellassa University, Badulla 90000, Sri Lanka \\ 5 National Water Supply and Drainage Board, Katugastota 20800, Sri Lanka; skwera7@gmail.com \\ 6 National Institute of Fundamental Studies, Hantana Road, Kandy 20000, Sri Lanka; rohan.we@nifs.ac.lk \\ * Correspondence: yswei@rcees.ac.cn; Tel.: +86-10-6284-9690
}

Received: 29 October 2019; Accepted: 26 November 2019; Published: 28 November 2019

\begin{abstract}
Installation of decentralized water-treatment plants is an ideal option to supply safe drinking water for rural communities. Presently in Sri Lanka, over 3.6 million villagers face acute water-quality problems, and chronic kidney disease of unknown etiology $(\mathrm{CKDu})$ is also prevalent among this community. Most of the drinking water in these villages is unpalatable due to high hardness and salinity. As an interim measure, reverse-osmosis (RO) water-treatment plants are introduced to provide safe water. However, due to deficient electrolytes, RO-treated water tastes unpleasant to some consumers; hence, people refuse it after prolonged use. The operation, maintenance, and management of RO plants are other major problems. Aimed at providing safe drinking water to the rural sector in a cost-effective manner, in this study, we fabricated an automated drinking-water purification system based on nanofiltration (NF) membrane technology, which can remove divalent cations, dissolved organic carbon (DOC) and pathogens efficiently, and monovalent ions partially, and thus keep electrolytes to some degree. Ten commercial NF membranes were tested in a laboratory, for solute and DOC removal efficiency and robustness. The DF-90 membrane showed the highest removal of DOC and hardness, and it was therefore selected, to design a pilot NF drinking-water treatment plant. The adhered $\mathrm{DOC}$ by the membrane can be cleaned by $\mathrm{NaOH}$ solution $(\mathrm{pH}=12)$. The pilot NF drinking-water treatment plant has been in use since September 2018, and it shows excellent performance of removing DOC, TDS, hardness, fluoride, and pathogens in groundwater, and the permeate water of the NF plant has been well-accepted by the stakeholders of the society. The dominant genus of source water, and throughout the two processes (NF and RO), is Pseudomonas, and their difference is significant in the concentrates of the NF and RO processes.
\end{abstract}

Keywords: chronic kidney disease of unknown etiology; nanofiltration; drinking water; decentralization; microbial pathogens 


\section{Introduction}

\subsection{Chronic Kidney Disease of Unknown Etiology (CKDu) in Sri Lanka}

In Sri Lanka, chronic kidney disease of unknown etiology (CKDu) was discovered over three decades ago and is epidemic among the rural farming community in the North Central Province (NCP), causing a severe national burden [1-3]. The CKDu has no relationship to known causes common to chronic kidney diseases such as obesity, hypertension, diabetes, or other factors, like snake bites. The factors controlling the prevalence and geographic distribution of the CKDu are not yet evident. In some areas, CKDu prevailing rate escalates from $2 \%$ to $15 \%$ [4,5]; presently, the total affected population by the disease is 400,000 , and the total death toll is over 20,000 [6,7]. Over thirty or so hypotheses are proposed to elucidate disease etiology without any conclusion. However, most of these hypotheses are somehow related to drinking-water quality. Therefore, the World Health Organization (WHO) recommends the provision of safe water to CKDu-affected zones [8]. The Government of Sri Lanka is committed to achieving the UN sustainable development goals by 2030, in which safe water and sanitation are high priorities. To date, various drinking-water treatment options are delivered to the CKDu-affected zones, as most of these areas are not covered by the national water-supply grid of Sri Lanka.

\subsection{Groundwater Quality in CKDu Areas}

Various researchers have investigated the water quality and CKDu prevalence in different parts of the endemic zones. The common nephrotoxic contaminants are hardness and fluoride in $\mathrm{Ca}-\mathrm{HCO}$ type water [9-11]. However, the studies toward the effect of water consumption on the incidence rate of CKDu is scarce to date. We examined the chemical quality of groundwater from different CKDu affected zones [12,13] and developed an integrated water quality index (WQI) [13] to demarcate water with high TDS, DOC, and fluoride in CKDu areas that requires treatment [14].

\subsection{Decentralized Drinking-Water Treatment}

The provision of decentralized water-treatment plants is the right choice, particularly in the rural villages of developing countries [15], where it is not sustainable to operate centralized water distribution and drainage systems [16,17]. Reliable disinfection of the treated water is of utmost importance due to its direct influence on human health [18]. A large number of domestic water plants distributed in villages include ceramic filters, candle filters, and packed RO purification systems [17,19]. However, most of these plants are abandoned due to maintenance issues [20]. For example, in Kenya, over $50 \%$ of household plants are nonfunctional after a year, due to lack of skilled labor, chemicals, spare parts, or robustness [21-23]. The provision of community-based water-treatment systems (with semi- or full automation) is an ideal option for providing drinking water for small villages, considering all issues related to training, operation, routine maintenance, and sustainable usage.

\subsection{Nanofiltration in Drinking-Water Production}

Nanofiltration (NF) is a process between reverse osmosis (RO) and ultrafiltration (UF), and it contains several advantages over the other methods, like high-quality effluent, low energy demand (smallest footprint), and smooth operation and maintenance. At present, NF membrane technology is widely used in treating various kind of waters, including drinking water, domestic wastewater, chemical industry water, pharmaceutical industry water, sugar industry water, and mining water. Nanofiltration was first used for drinking-water production in the 1980s, treating hard and colored water in Florida, USA [24]. The NF membrane technology is capable of removing dissolved organic molecules (i.e., micro-pollutants, disinfection by-products), and viruses. Most important, it can also partially treat a significant proportion of dissolved salts. This property of NF offers an attractive alternative over $\mathrm{RO}$ to retain natural water signatures in the permeate. In RO technology, however, the dissolved salts in water are removed, and, subsequently, pure inorganic salts are added to keep the 
ionic balance. Nanofiltration has shown promising results for the removal of drinking-water pollutants in rural areas, utilizing renewable energy sources [25,26].

In this study, a decentralized automated NF-membrane-based pilot drinking-water treatment plant was fabricated to meet the stringent water requirements in a CKDu-affected zone in Sri Lanka. Based on our previous data [14], a suitable NF membrane was selected out of ten commercial brands with the highest TDS and DOC rejection. Then, a drinking-water treatment plant equipped with the selected NF membrane was fabricated and installed in a CKDu-prevalent area of Sri Lanka, and its performance was investigated for one year.

\section{Materials and Methods}

\subsection{Synthetic Groundwater}

Distilled water was spiked with known concentrations of $\mathrm{CaCl}_{2}$ and $\mathrm{MgSO}_{4}$ (Sinopharm, Shanghai, China) and humic acids (Sigma-Aldrich, St. Louis, MO, USA) to match water hardness and DOC concentrations in the natural groundwater of a CKDu-prevalent area of Sri Lanka [14].

\subsection{Experimental Setup and Membranes}

Ten NF 1812 series commercial spiral-wound membranes (Table 1) were used in a laboratory setup (Figure 1), to test the salt and DOC rejection. Experiments were carried out in cross-flow mode, circulating both concentrate and permeate back to the feed tank.

Table 1. Characteristics of the tested nanofiltration (NF) 1812 spiral-wound membranes.

\begin{tabular}{llllc}
\hline No. & Model/type & Manufacturer & Material & MWCO (Molecular Weight Cut-Off) \\
\hline 1 & DK1812 & GE & Polyamide & $150-300$ \\
2 & DL1812 & GE & Polyamide & $150-300$ \\
3 & NFX-1812 & Synder & Polyamide & $150-300$ \\
4 & NFG-1812 & Synder & Polyamide & $600-800$ \\
5 & NF4-1812 & Nanostone & Polysulfone & $\sim 150$ \\
6 & NF8-1812 & Nanostone & Polysulfone & $\sim 300$ \\
7 & DF-90-1812 & Origin Water & Polyamide & $\sim 400$ \\
8 & NF1-1812-75 & Keensen & Polyamide & \\
9 & JCM-1812-75N & HN-JCM & Polyamide & \\
10 & GL-1812-75N & Gallon & Polyamide & \\
\hline
\end{tabular}

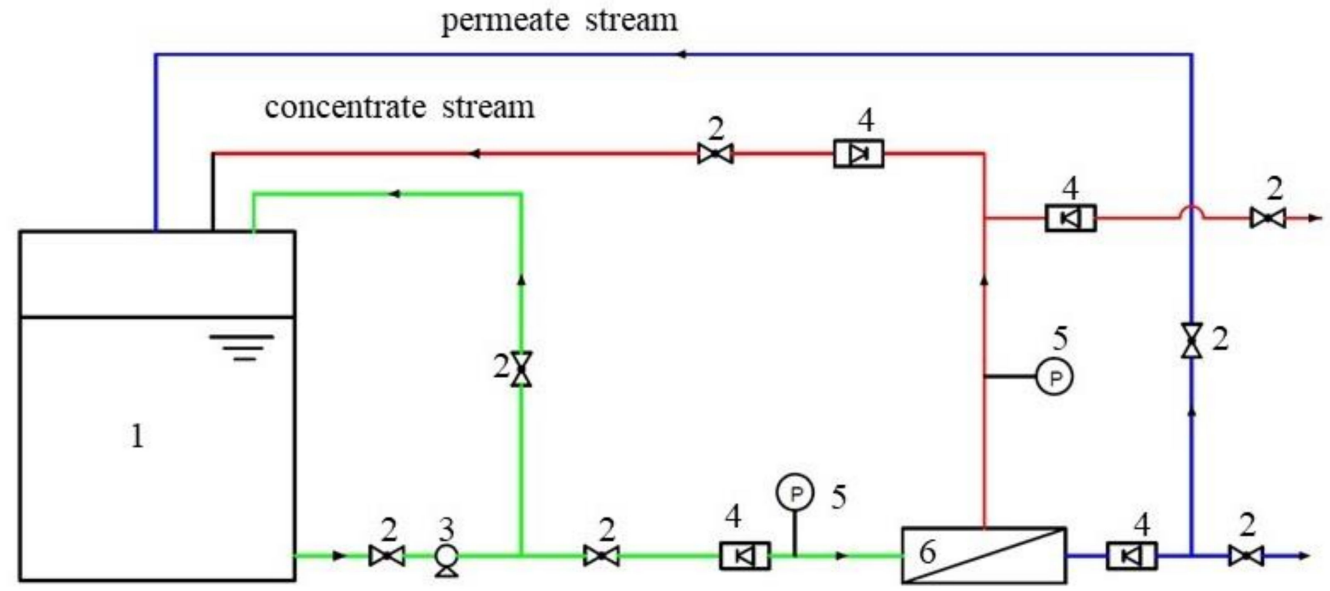

Figure 1. Scheme of the NF laboratory setup. (1) feed tank, (2) regulation valve, (3) feed pump, (4) rotameter, (5) manometer, and (6) NF module. 


\subsection{Membrane Cleaning}

Membrane fouling test was performed for the DF-90 membrane, using the same experimental setup (Figure 1), at $0.4 \mathrm{MPa}$ pressure and $20.0 \mathrm{~L} / \mathrm{h}$ cross-flow velocity, for $168 \mathrm{~h}$, at ambient conditions. Membrane cleaning was carried out, using the solutions listed in Table 2. The fouled NF membrane was divided into 10 pieces and soaked in the following solutions, respectively, for $24 \mathrm{~h}$, before imaging by a scanning electron microscope (Quattro C, Thermo Scientific, Waltham, MA, USA).

Table 2. Details of solutions used for DF-90 membrane cleaning.

\begin{tabular}{rll}
\hline No. & Solution & $\mathbf{p H}$ \\
\hline 1 & $\mathrm{DI}$ water & 7.0 \\
2 & $\mathrm{HCl}$ & 2.0 \\
3 & $\mathrm{NaOH}$ & 12.0 \\
4 & $\mathrm{NaOH}(0.1 \% \mathrm{w})+\mathrm{SDS}(0.025 \% \mathrm{w})$ & 12.0 \\
5 & $\mathrm{Acetic}$ & 3.0 \\
6 & $\mathrm{NaOCl}$ & 10.0 \\
7 & $\mathrm{HCl}$ then $\mathrm{NaOH}$ & $2.0 / 12.0$ \\
8 & $\mathrm{NaOH}$ then $\mathrm{HCl}$ & $12.0 / 2.0$ \\
9 & $\mathrm{Acetic}$ then $\mathrm{NaOCl}$ & $3.0 / 10.0$ \\
10 & $\mathrm{NaOCl}$ then $\mathrm{Acetic}$ & $10.0 / 3.0$ \\
\hline
\end{tabular}

\subsection{Analytical Methods}

The $\mathrm{pH}$, electrical conductivity (EC), and temperature of the water were measured by multi-electrode probes equipped with a multi-parametric analyzer (WTW, Welheim, Germany). The concentrations of major cations were determined by an inductively coupled plasma optical emission spectrophotometer (Optima 8300, Perkin Elmer, Houston, TX, USA). The concentrations of trace cations and metalloids were analyzed by an inductively coupled plasma mass spectrophotometer (NexION 300X Perking Elmer, Houston, TX, USA). The concentrations of all anions were measured by an ion chromatography (ICS-1000, Dionex, Sunnyvale, CA, USA). Hardness was calculated from the concentrations of divalent ions (Equation S1). The dissolved organic carbon (DOC) concentration was analyzed by a TOC analyzer (Vario TOC, Elementra, Langenselbold, Germany). The fluorescence intensity of DOC was investigated by using 3D Excitation Emission Matrices (3D-EEM) and fluorescence spectrophotometer (F-7000, Hitachi, Tokyo, Japan). The molecular weight (MW) distribution of DOC was measured by a high-performance size-exclusion chromatography (HPSEC, Breeze 1525, Waters, Milford, MA, USA).

\subsection{Pilot Drinking-Water Station}

The pilot drinking-water station was constructed by using DF-90 nanofiltration membranes (Type 4040, Origin Water, China). As shown in Figure 2 and Table S1, pretreatment and disinfection processes were added in this drinking-water station.

\subsection{Microbial Community Analysis}

Water samples from the NF (Sirimapura, latitude-8.1590 and longitutde-80.2410) and RO (Rajanganay, latitude-8.1644 and longitutde-80.1907) plants were collected. The microbial communities of the source groundwater, permeate, and concentrate streams of the NF and RO plants were analyzed and compared.

Water samples $(0.5 \mathrm{~L})$ were vacuum-filtered, using $0.22 \mu \mathrm{m}$ membrane filters. The membrane filters were cut into pieces for the DNA extraction, using the FAST DNA Spin Kit (MP Biomedicals, USA). Extracted genomic DNA was detected by using $1 \%$ agarose gel electrophoresis and quantified with NanoDrop 2000 (Thermo Scientific, USA). The samples were stored at $-20^{\circ} \mathrm{C}$ before use. The microbial communities were evaluated with 515F/806R primers, targeting the bacterial and archaeal microbes of 
$16 \mathrm{~S}$ rRNA genes. Sequencing was carried out through pair-end Illumina sequencing (Illumina Miseq, USA) at Sangon Co., Ltd. (Shanghai, China). Pair-end reads were merged (PEAR: $-x, 0.1$ ) and assigned to each sample according to the unique barcode; the merged reads were quality controlled (PRINSEQ) and chimers filtered (USEARCH), to get clean sequences; the clean sequences were normalized and submitted to the NCBI Sequence Read Archive (SRA). The taxonomic classification was carried out, using the Ribosomal Database Project (RDP) classifier, with the taxon below $0.01 \%$ removed, and the RDP associated modules calculated the diversity indexes.

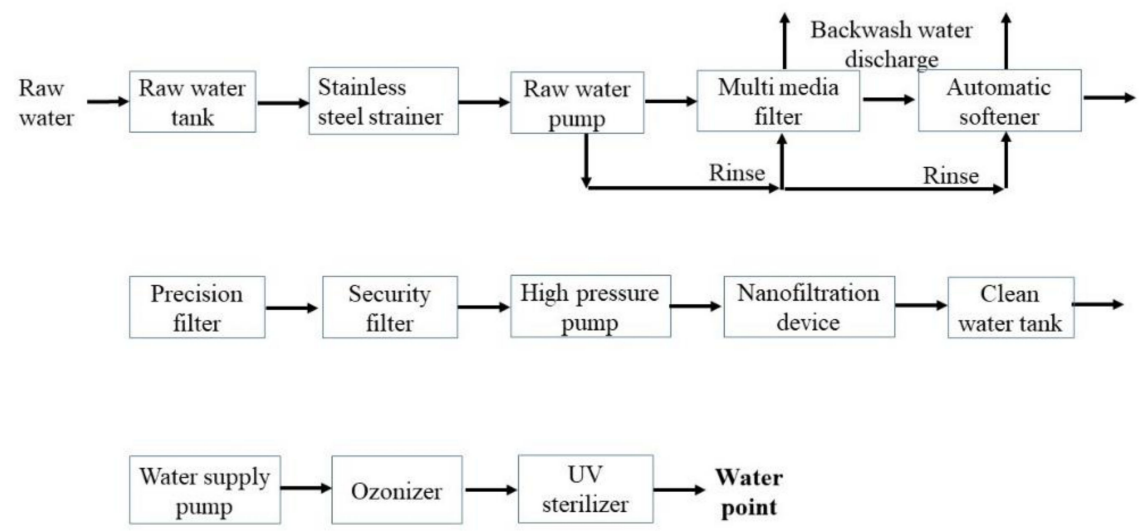

Figure 2. The water treatment process of pilot setup, using NF membrane technology.

\section{Results and Discussions}

\subsection{Selection and Morphological Analysis of Membrane}

Ten 1812-series commercial NF membranes (Table 1) were tested in our laboratory, and the variation of permeate flux and hardness vs. applied pressure of commercial membranes was shown in Figure 3a,b. NF-75 membrane shows the highest permeate flux, with low hardness rejection. DF-90, Gallon, and DK nanofiltration membranes show the top three highest hardness rejection; therefore they were selected for further study.
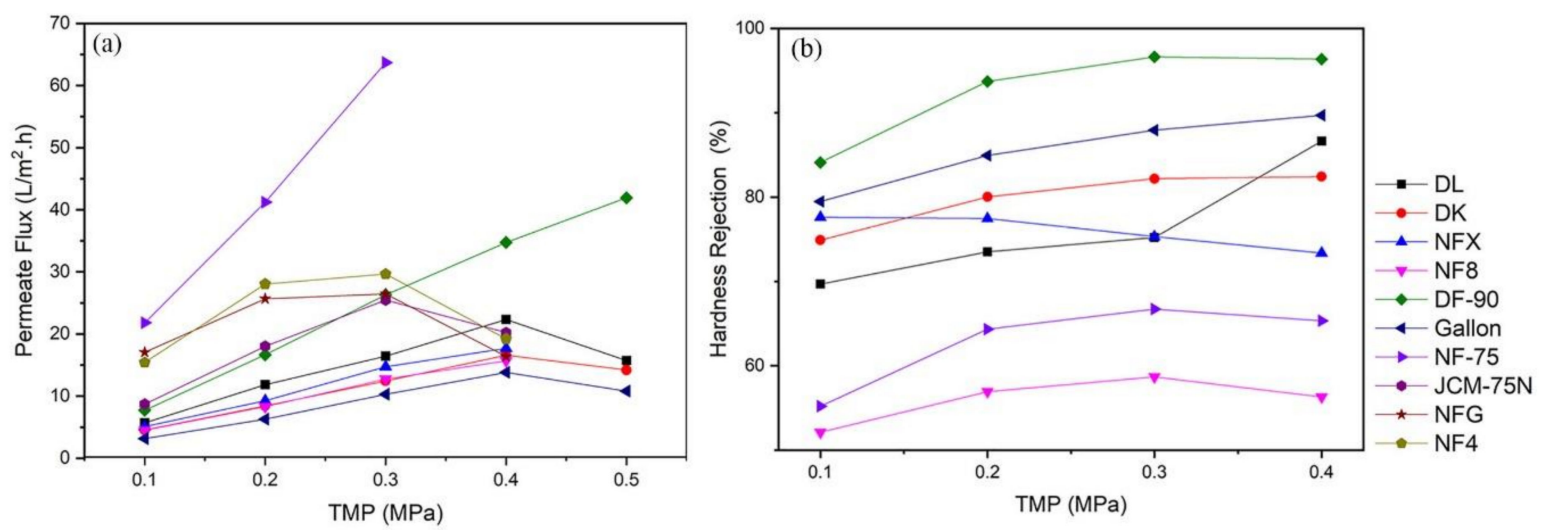

Figure 3. Variation of tested NF membranes in permeate flux (a) and hardness rejection (b).

In these three NF membranes (Figure 4a), only the DF-90 membrane showed the highest DOC rejection (Figure 4b); therefore, it was chosen for construction of a drinking-water treatment plant. 

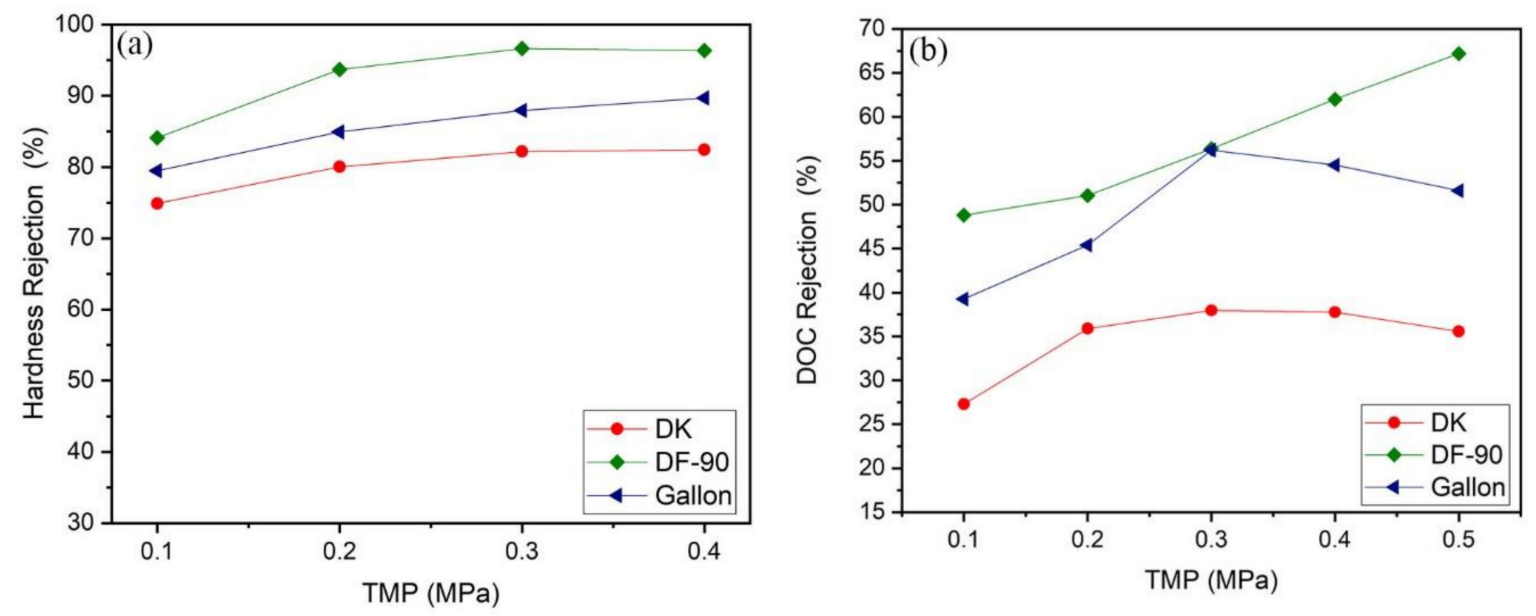

Figure 4. Hardness rejection ability (a) and DOC rejection ability (b) of DK, DF-90, and Gallon membranes.

The SEM images of both cleaned and fouled DF-90 membranes are shown in Figure 5. The SEM images were used to identify the surface morphological features of virgin, fouled, and cleaned membranes, as described by Wang et al. 2017 [27].

The surface pattern of the virgin NF membrane is uniform with a ripple-like structure (Figure 5a). The ripple-like pattern is almost perturbed in the fouled membrane (Figure 5b). The images of NF membrane surface after cleaning with different solutions are shown from Figure $5 c-1$. The distilled water cleaning is not efficient to restore membrane surface to virgin conditions. Improvement of the surface structure with $\mathrm{HCl}$ or acetic acid treatment is moderate. When $\mathrm{NaOCl}$ or $\mathrm{NaOCl}$-acetate treatments are applied, some alteration in the surface is noted [28]. However, when treated with $\mathrm{NaOH}$, the ripple-like structure of the membrane surface is almost restored (Figure 5i). These results clearly showed that the major foulant of DF-90 membrane is organic matter. Therefore, flushing with $(\mathrm{pH}=12) \mathrm{NaOH}$ is recommended to clean the DF-90 membrane. When compared to other membrane cleaning chemicals, $\mathrm{NaOH}$ is not costly [29].

\subsection{Performance of Pilot Drinking-Water Station}

The use of one single treatment technology is not sufficient to meet the industrial objectives, especially not to meet the regulation levels; therefore, in a treatment plant, many processes are combined together [24]. The performance of NF membranes to remove hardness, fluoride, DOC, and TDS was evaluated with synthetic water, where no pretreatment method is required. However, for natural groundwater treatment of CKDu affected areas, several pretreatment steps are required to remove color, turbidity, hardness, or DOC to keep stable operation and extend NF membrane lifetime in this study (Table S1). 


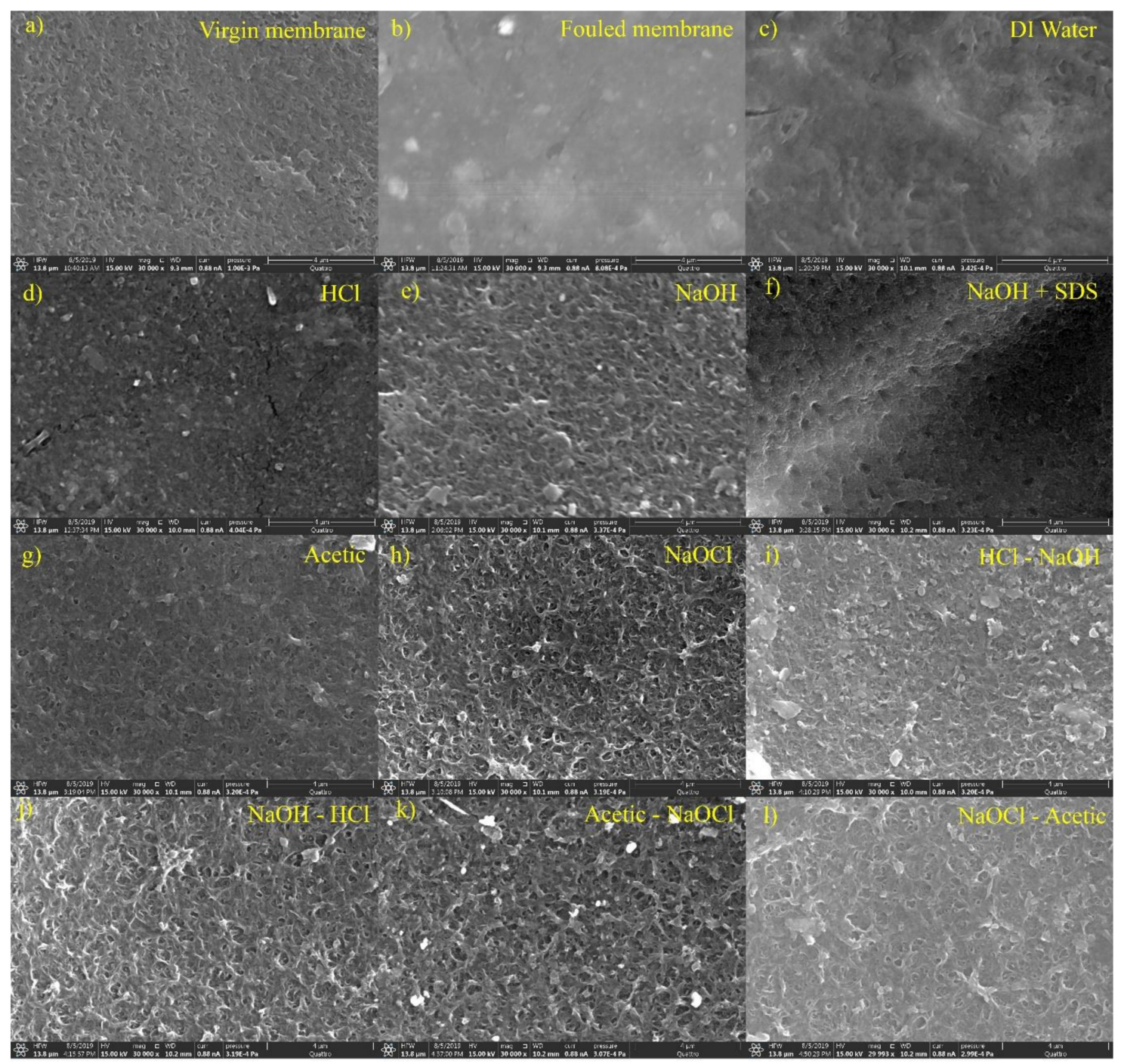

Figure 5. Comparison of SEM images of virgin, fouled, and cleaned DF-90 membranes. (a) virgin membrane, (b) fouled membrane, (c) membrane cleaned with DI water, (d) membrane cleaned with $\mathrm{HCl}$, (e) membrane cleaned with $\mathrm{NaOH}$, (f) membrane cleaned with $\mathrm{NaOH}+\mathrm{SDS}$, (g) membrane cleaned with acetic acid, (h) membrane cleaned with $\mathrm{NaOCl}$, (i) membrane cleaned with first $\mathrm{HCl}$ then $\mathrm{NaOH},(\mathbf{j})$ membrane cleaned with first $\mathrm{NaOH}$ then $\mathrm{HCl},(\mathbf{k})$ membrane cleaned with first acetic then $\mathrm{NaOCl}$ and (l) membrane cleaned with first $\mathrm{NaOCl}$ then acetic.

The pretreatment steps can retard the NF membrane fouling. Nanofiltration (NF) is combined with microfiltration (MF) and ultrafiltration (UF) as pretreatment steps to remove turbidity, color, and DOC. Scaling can form by precipitation of inorganic salts on the membrane surface [29]. For example, to avoid calcium carbonate precipitation, sulfuric acid at negative $0.2 \mathrm{pH}$ LSI (Langelier Saturation Index) is added to the feedwater [29]. Lime softening is carried out to remove $\mathrm{Mg}^{2+}$ and Ca ${ }^{2+}$ before their reaching the membrane [24]. Conventional sand and carbon cartridge filters are also used to remove the particulate matter and colloids. Greensand filters are used to remove iron and magnesium ions from feed water [24]. Activated carbon (AC) and granular activated carbon (GAC) prepared from various materials are also used as a pretreatment to remove natural organic matter (NOM), synthetic organic compounds (SOCs), and disinfectant byproducts (DBPs) [30]. In this study, based on our previous study [14], the pilot drinking-water treatment plant is thus equipped with a multimedia filter (sand and activated carbon), cation exchange resin, precision filter, and security filter to reduce membrane fouling of DF-90 (Table S1). The cation exchange resin (named as automatic softener in this study) reduces the amount of $\mathrm{Ca}^{2+}$ and $\mathrm{Mg}^{2+}$ ions for controlling the NF membrane scaling [31]. 
A pilot drinking-water treatment plant at the design capacity of $20 \mathrm{~m}^{3} /$ day (Figure S1) was installed in September 2018, at Sirimapura's Community-Based Organization (CBO) (latitude-8.159, longitude-80.241/141472E, 328148N), Rajanganaya divisional secretariat of Anuradhapura district, Sri Lanka (CBO is a villagers-based government organization in Sri Lanka to ensure safe drinking water for a community). The village consists of 164 households with about 750 residents. The CBO extracts water from a dug well into a $75 \mathrm{~m}^{3}$ water storage tower ( $15 \mathrm{~m}$ height) during daytime, for distribution after disinfection, and a man-made reservoir recharges the aquifer in the vicinity. Groundwater quality of the dug well used for water extraction (Table 3) has a moderate hardness and fluoride concentrations.

Table 3. Chemical characteristics of raw water, permeate, and concentrate of the pilot NF plant.

\begin{tabular}{|c|c|c|c|c|c|}
\hline \multirow{2}{*}{ Parameter } & \multirow{2}{*}{ Units } & \multirow{2}{*}{ SLS 614: 2013} & \multicolumn{3}{|c|}{ Sample Date-13 September 2018} \\
\hline & & & Raw & Permeate & Concentrate \\
\hline Color & Hazen units & 15 & 18 & 4 & 20 \\
\hline Turbidity & NTU & 2 & 0.7 & 0.4 & 0.9 \\
\hline Electrical Conductivity & $\mu \mathrm{s} / \mathrm{cm}$ & 750 & 565 & 24 & 1523 \\
\hline $\mathrm{pH}$ & - & $6.5-8.5$ & 7.17 & 6.4 & 7.7 \\
\hline Chloride (as Cl) & $\mathrm{mg} / \mathrm{L}$ & 250 & 11 & 3 & 6 \\
\hline $\begin{array}{l}\text { Total Alkalinity (as } \\
\mathrm{CaCO}_{3} \text { ) }\end{array}$ & $\mathrm{mg} / \mathrm{L}$ & 200 & 306 & 24 & 684 \\
\hline Total Hardness (as $\mathrm{CaCO}_{3}$ ) & $\mathrm{mg} / \mathrm{L}$ & 250 & 200 & 4 & 500 \\
\hline Free Ammonia (as $\mathrm{NH}_{3}$ ) & $\mathrm{mg} / \mathrm{L}$ & 0.06 & ND & ND & ND \\
\hline Nitrate $\left(\right.$ as $\left.\mathrm{NO}_{3}\right)$ & $\mathrm{mg} / \mathrm{L}$ & 50 & 0.4 & 0.3 & 0.5 \\
\hline Nitrite (as $\mathrm{NO}_{2}$ ) & $\mathrm{mg} / \mathrm{L}$ & 3 & 0.01 & 0.01 & 0.01 \\
\hline Fluorides (as F) & $\mathrm{mg} / \mathrm{L}$ & 1 & 1.3 & 0.01 & 1.5 \\
\hline Phosphates (as $\mathrm{PO}_{4}$ ) & $\mathrm{mg} / \mathrm{L}$ & 2 & 0.3 & 0.4 & 0.3 \\
\hline Iron (as Fe) & $\mathrm{mg} / \mathrm{L}$ & 0.3 & ND & ND & ND \\
\hline Manganese (as Mn) & $\mathrm{mg} / \mathrm{L}$ & 0.1 & 0.05 & 0.08 & 0.09 \\
\hline Calcium (as $\left.\mathrm{CaCO}_{3}\right)$ & $\mathrm{mg} / \mathrm{L}$ & 100 & 136 & 3 & 4 \\
\hline
\end{tabular}

The pilot drinking-water treatment plant operates at $0.5 \mathrm{MPa}$ pressure, with $8 \mathrm{LPM}$ permeate flux. The permeate water recovery is set at around $40 \%$. Table 3 shows the water quality of raw water, permeate, and concentrate during the initial stage of the plant operation. Due to the presence of an ion exchange resin, the level of $\mathrm{Ca}^{2+}$ in the concentrate is low, and the concentrate can be used as irrigation water [32,33]. Villagers use the permeate water for their daily drinking/cooking purposes at 1 LKR per liter. The plant is managed by "Nildiya" CBO officials of the Sirimapura village. At present, over $1500 \mathrm{~L}$ of permeate water is sold daily, and the income is sufficient to cover expenses (Table 4) and maintenance.

Table 4. Cost analysis of the NF drinking-water plant per month in LKR.

\begin{tabular}{lccc}
\hline Type & Units/Rate & Amount & Total \\
\hline Direct income & $1500 \times 1 \times 30$ & 45,000 & 45,000 \\
Water selling & & 15,000 & \\
Direct expenditure & 5000 & 20,000 \\
Salary for operator & & 25,000 \\
Electricity bill & & & \\
Savings for the month & & & \\
\hline
\end{tabular}

Note: 1 LKR (Sri Lankan Rupee) = 1/180 USD in 2019 November.

\subsubsection{Water Quality of Permeate}

The NF drinking-water station has been in stable operation for over a year (Table 5 and Figure 6), and its permeate water quality meets the Sri Lankan drinking-water quality standards (SLS 614: 2013) [34] because the National Water Supply and Drainage Board (NWSDB, national authority in Sri 
Lanka for the provision of safe water to the nation) has monitored the water quality since September 2018 (Table 5). The DOC rejection performance of the NF drinking treatment station is much better compared to the laboratory tests due to pretreatment processes, and most of the DOC components of raw water were removed, as shown in Figure 7.

Table 5. Permeate water quality of the pilot NF drinking-water station since September 2018.

\begin{tabular}{|c|c|c|c|c|c|c|}
\hline Parameter & Units & $\begin{array}{l}\text { SLS 614: } \\
2013\end{array}$ & $\begin{array}{l}13 \text { September } \\
2018\end{array}$ & $\begin{array}{l}27 \text { September } \\
2018\end{array}$ & $\begin{array}{l}18 \text { April } \\
2019\end{array}$ & 11 July 2019 \\
\hline Color & Hazen & 15 & 4 & 0 & 0 & 0 \\
\hline Turbidity & NTU & 2 & 0.40 & 0.10 & 0.36 & 1.05 \\
\hline Electrical Conductivity & $\mu \mathrm{s} / \mathrm{cm}$ & 750 & 24 & 28 & 30 & 40 \\
\hline $\mathrm{pH}$ & & $6.5-8.50$ & 6.40 & 6.50 & 6.65 & 7.16 \\
\hline Chloride (as Cl) & $\mathrm{mg} / \mathrm{L}$ & 250 & 3 & 2 & 9 & 10 \\
\hline Total Alkalinity (as $\mathrm{CaCO}_{3}$ ) & $\mathrm{mg} / \mathrm{L}$ & 200 & 24 & 12 & 17 & 16 \\
\hline Total Hardness (as $\mathrm{CaCO}_{3}$ ) & $\mathrm{mg} / \mathrm{L}$ & 250 & 4 & 10 & 10 & 18 \\
\hline Free Ammonia (as $\mathrm{NH}_{3}$ ) & $\mathrm{mg} / \mathrm{L}$ & 0.06 & ND & ND & 0.06 & 0.06 \\
\hline Nitrate $\left(\right.$ as $\left.\mathrm{NO}_{3}\right)$ & $\mathrm{mg} / \mathrm{L}$ & 50 & 0.3 & 2.60 & ND & 0.44 \\
\hline Nitrite (as $\mathrm{NO}_{2}$ ) & $\mathrm{mg} / \mathrm{L}$ & 3 & 0.01 & 0.01 & 1.90 & ND \\
\hline Fluorides (as F) & $\mathrm{mg} / \mathrm{L}$ & 1 & 0.01 & 0.12 & 0.20 & 0.10 \\
\hline Phosphates (as $\mathrm{PO}_{4}$ ) & $\mathrm{mg} / \mathrm{L}$ & 2 & 0.4 & ND & 0.07 & 0.94 \\
\hline Iron (as Fe) & $\mathrm{mg} / \mathrm{L}$ & 0.3 & ND & 0.1 & 0.03 & 0.01 \\
\hline Manganese (as Mn) & $\mathrm{mg} / \mathrm{L}$ & 0.1 & 0.08 & ND & ND & 0.01 \\
\hline Calcium (as $\mathrm{CaCO}_{3}$ ) & $\mathrm{mg} / \mathrm{L}$ & 100 & 4 & 3 & 7 & - \\
\hline
\end{tabular}
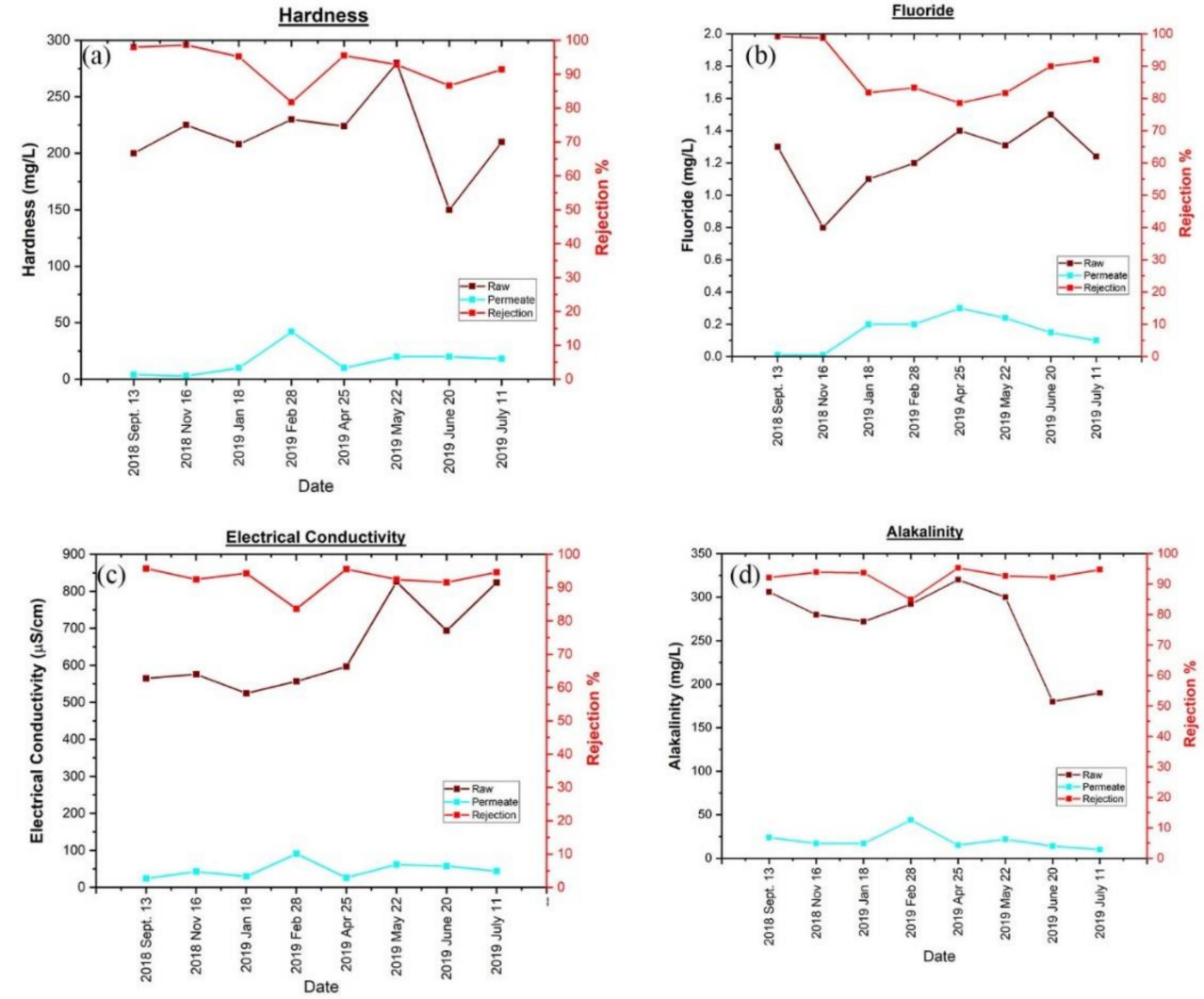

Figure 6. Raw water, permeate concentration and rejection level variation of hardness (a), fluoride (b), electrical conductivity (c), and alkalinity (d) over the time of NF drinking plant. 

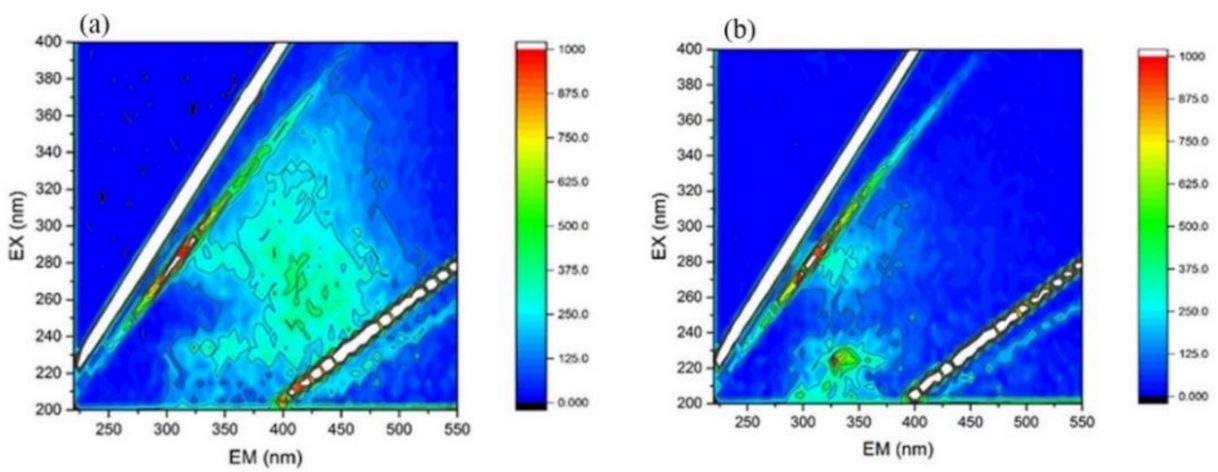

(c)
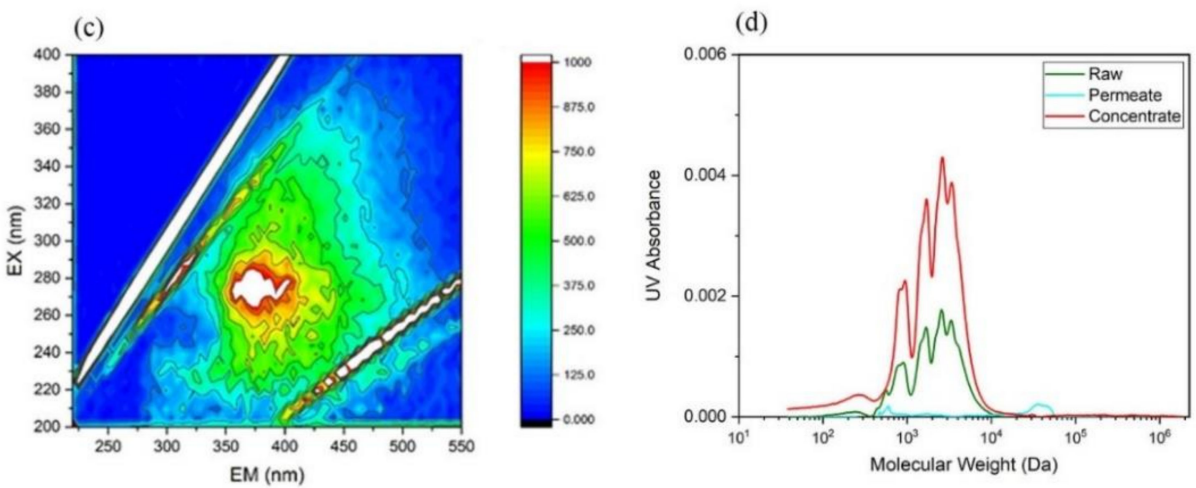

Figure 7. Contains 3DEEM spectra of (a) raw water (b) permeate (c) concentrate and (d) molecular weight distribution of three samples in the NF drinking-water plant.

\subsubsection{Water-Quality Comparison of NF and RO Treatment Plants}

The NF plant is in stable operation till now because routine cleaning processes are automated in this NF drinking-water plant, and thus most of the issues arising from manual maintenance routes are minimized [35]. The water quality of the permeate of the NF and RO plants was compared in CKDu areas. Most $\mathrm{RO}$ plants produce low $\mathrm{pH}$ permeate water (commonly $\mathrm{pH}<7$ ), and the concentrations of major ions like $\mathrm{Na}, \mathrm{K}, \mathrm{Ca}$, and $\mathrm{Mg}$ are low in the permeate (Table 6), which causes complaints from the stakeholders about water palatability [36]. However, the major ions are present at appreciable concentrations in the NF permeate, which thus are well accepted by the stakeholders and residents.

Table 6. Comparison of the permeate water quality of the RO plants and NF plant.

\begin{tabular}{|c|c|c|c|c|c|c|c|c|c|}
\hline \multirow{2}{*}{ Parameter } & \multicolumn{8}{|c|}{ RO Plant } & \multirow{2}{*}{$\begin{array}{c}\text { NF } \\
\text { Plant }\end{array}$} \\
\hline & RO 1 & RO 2 & RO 3 & RO 4 & RO 5 & RO 6 & RO 7 & RO 8 & \\
\hline $\mathrm{pH}$ & 6.95 & 7.00 & 6.84 & 5.74 & 5.66 & 5.96 & 6.40 & 7.30 & 7.00 \\
\hline $\mathrm{EC}(\mu \mathrm{s} / \mathrm{cm})$ & 35 & 16 & 30 & 36 & 15 & 31 & & 102 & 43 \\
\hline Alkalinity (mg/L) & nd & nd & 1.4 & 4.9 & nd & 10 & 19 & 20 & 29 \\
\hline $\mathrm{Mg}(\mathrm{mg} / \mathrm{L})$ & nd & nd & nd & nd & nd & nd & nd & nd & 1.14 \\
\hline $\mathrm{Ca}(\mathrm{mg} / \mathrm{L})$ & nd & nd & 0.75 & 0.33 & 0.15 & 0.94 & 2.02 & 3.05 & 2.43 \\
\hline Hardness $(\mathrm{mg} / \mathrm{L})$ & nd & nd & 1.86 & 0.82 & 0.37 & 2.35 & 5.05 & 8.88 & 10 \\
\hline $\mathrm{K}(\mathrm{mg} / \mathrm{L})$ & nd & nd & 0.14 & 0.31 & 0.07 & 0.48 & 0 & 0 & 0.21 \\
\hline $\mathrm{Na}(\mathrm{mg} / \mathrm{L})$ & 6.51 & 3.27 & 5.24 & 7.73 & 3.26 & 5.11 & 6.90 & 16.85 & 4.38 \\
\hline $\mathrm{Cl}^{-}(\mathrm{mg} / \mathrm{L})$ & 7.11 & 2.88 & 2.48 & 3.02 & 39.96 & 4.95 & 1.66 & 19.15 & 1.16 \\
\hline $\mathrm{F}^{-}(\mathrm{mg} / \mathrm{L})$ & 2.56 & 2.89 & 0.04 & 0.50 & 0.40 & 0.40 & 0.07 & 0.07 & nd \\
\hline $\mathrm{SO}_{4}{ }^{2-}(\mathrm{mg} / \mathrm{L})$ & 4.34 & 3.79 & 2.52 & 2.21 & 4.28 & 4.46 & 1.12 & 1.75 & 0.57 \\
\hline $\mathrm{Fe}(\mathrm{ng} / \mathrm{L})$ & 2.3 & nd & 0.1 & 0.1 & nd & 0.4 & 8.5 & 4.0 & 1.4 \\
\hline $\mathrm{DOC}(\mathrm{mg} / \mathrm{L})$ & 1.40 & 1.70 & 0.01 & 0.48 & 0.35 & 2.18 & 0.53 & 0.30 & 0.90 \\
\hline
\end{tabular}

Note: Location of RO plants are given in Table S2; nd = not detected. 


\subsubsection{Comparative Analysis of the Microbial Community between RO and NF Treated Water}

The dominant bacteria belonged to the Proteobacteria is present at above $50 \%$ in the source water (Figure 8). The relative abundances of Proteobacteria in the permeate in the RO (RO_P) and NF (NF_P) treatment are $92.2 \%$ and $96.1 \%$, respectively, but the relative abundance of Proteobacteria in the concentrate of NF (NF_C) reaches $81.2 \%$, higher than that of RO (RO_C). The relative abundance of Proteobacteria increases after the RO and NF membrane treatment. The RO and NF membrane treatment process effectively reduces the Actinobacteria from $14.6 \%$ to $0.5 \%$ and from $18.3 \%$ to $0.4 \%$, respectively. However, the relative abundance of Actinobacteria in the concentrate of RO (13.7\%) is higher than that of NF (2.0\%). The diversity of the microbial community in the RO concentrate (RO_C) is much higher than that of NF (NF_C). These results clearly show that the disinfection unit of the NF drinking-water station plays an important role in controlling microbes in the permeate.

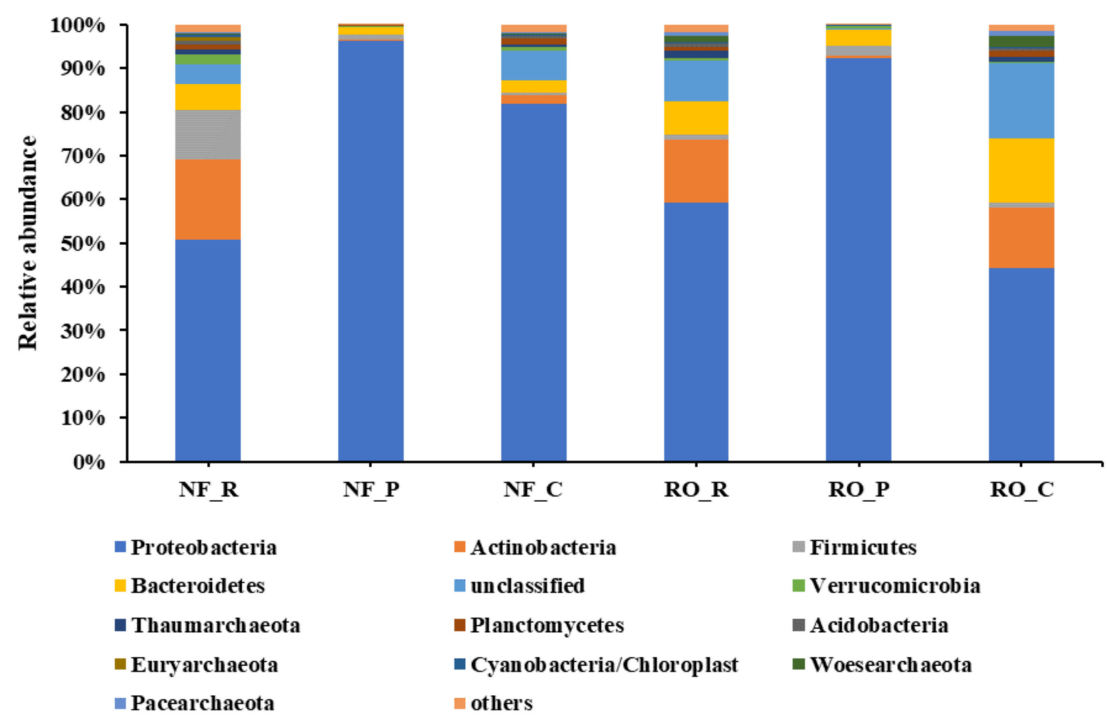

Figure 8. Relative abundance of microbial community of the RO and NF processes at the phylum level. (NF-nanofiltration, $\mathrm{RO}$-reverse osmosis, $\mathrm{R}$-raw water, $\mathrm{P}$ - permeate, and $\mathrm{C}$-concentrate).

As shown in Figure 9, the dominant genus in the source water is the Pseudomonas, and the relative abundances of Pseudomonas in the NF_P and RO_P are 93.5\% and 86.9\%, respectively. The Pseudomonas function is multifaceted. For example, the Pseudomonas exhibits enhanced denitrification, resistance of heavy metals, organic pollutants, and antibiotics [37-40], and the presence of Pseudomonas also promotes the formation of biofilms in the water treatment, which helps improve water quality [41,42]. The Pseudomonas contains clinically important human pathogen P. aeruginosa, agriculturally important plant pathogen P. syringae, and nonpathogenic bioremediation agent P.putida [43]. P. aeruginosa is a major opportunistic human pathogen, notable for its ability to form biofilm and best-characterized quorum-sensing systems among Gram-negative bacteria, which can cause a variety of infections, ranging from eye infections in contact-lens wearers, burn and wound infections leading to septic shock, and lung infections in cystic fibrosis patients [44]. Nonetheless, the genus exists as pathogens in the drinking water require further investigation, using advanced methods, such as virulence factor analysis. Potential human pathogens, like Enterococcus and Acinetobacter, exist in water, and both NF and $\mathrm{RO}$ processes can reduce them from $7.0 \%$ to below $0.1 \%$ in the permeate. 


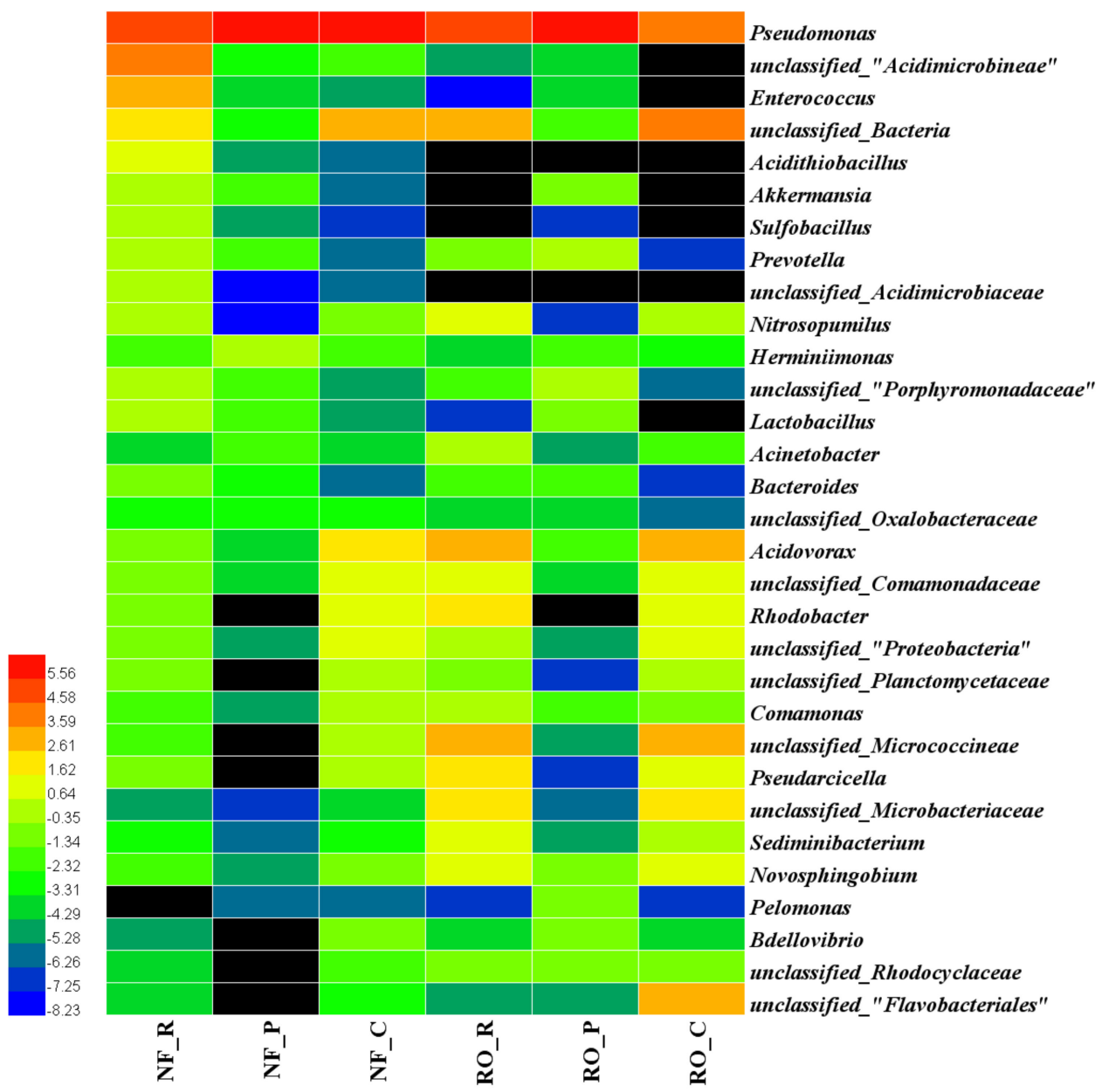

Figure 9. Microbial community (genus level) in RO and NF drinking-water treatment plants. (R-raw water, $\mathrm{P}$ - permeate, and $\mathrm{C}$-concentrate).

The Pseudomonas microbial community of the permeates in the RO and NF treatment shows similar patterns. The difference of the Pseudomonas abundance is shown in their concentrates. The abundance of Pseudomonas in the NF_C $(58.5 \%)$ is much higher than in the RO_C $(14.3 \%)$, while the relative abundance of Acidovorax in the RO_C reaches 9.0\%, while it is 3.1\% in the NF_C. Higher proportions of unclassified_Micrococcineae are also present in RO_C (8.0\%) compared to NF_C $(0.9 \%)$.

\section{Conclusions}

Ten commercially available NF membranes were tested for the rejection efficiency of hardness and DOC by the membranes, and the DF-90 membrane was selected due to its highest removal of $\mathrm{DOC}$ and hardness, for the construction of a pilot drinking-water treatment plant. The $\mathrm{NaOH}$ can be effectively used to remove foulants formed on the DF-90 membrane. The pilot drinking-water treatment plant equipped with the DF-90 membrane was installed and in the stable operation in a village of the CKDu-affected area of Sri Lanka since September 2018. This is the first time to use NF membrane technology to treat groundwater in Sri Lanka, and the removals of hardness, fluoride, and DOC by the NF pilot treatment plant is satisfactory. The permeate water quality of the NF plant meets the Sri Lankan drinking-water standards (SLS 614: 2013) and is well accepted by the stakeholders of the society. The Pseudomonas genus is dominant in source ground water, the microbial community in RO and NF permeates shows similar patterns, but a significant difference of the microbial community abundance was observed in their concentrates. The NF drinking-water plant is managed by "Nildiya" $\mathrm{CBO}$, and its generated income is promising for its operation and maintenance. 


\section{Future Research Directions}

During the long-term operation of the pilot plant, membrane fouling (scaling, organic, and biological fouling) mechanisms, and their mitigation measures require further examination. A detailed study of human pathogen distribution patterns in drinking-water sources and their appropriate treatment methods needs to be carried out based on virulence factor analysis.

Supplementary Materials: The following are available online at http://www.mdpi.com/2073-4441/11/12/2512/s1. Table S1. The list of equipment used in pilot plant construction. Figure S1. Constructed NF water treatment station. Table S2. Location of the RO plants.

Author Contributions: T.C.; Conceptualization, investigation, formal analysis, writing-original draft. Y.W.; conceptualization, methodology, writing-review and editing, supervision. J.Z.; formal analysis and writing original -draft, L.Z.; formal analysis. H.Z.; resources. S.K.W.; investigation. R.W.; writing-review and editing.

Funding: This research received no external funding

Acknowledgments: The authors gratefully acknowledge the financial support from the Program of China-Sri Lanka Joint Center for Water Technology Research and Demonstration by the Chinese Academy of Sciences (CAS); China-Sri Lanka Joint Center for Education and Research by the CAS; the Joint Research Program of National Natural Science Foundation of China and National Science Foundation of Sri Lanka (NSFC-NSF SL) (21861142020) and the Chinese Government Scholarship Program (CSC No. 2015GXYG44).

Conflicts of Interest: The authors declare no conflicts of interest.

\section{References}

1. Dharma-wardana, M.W.C.; Amarasiri, S.L.; Dharmawardene, N.; Panabokke, C.R. Chronic kidney disease of unknown aetiology and ground-water ionicity: Study based on Sri Lanka. Environ. Geochem. Health 2015, 37, 221-231. [CrossRef] [PubMed]

2. Rango, T.; Jeuland, M.; Manthrithilake, H.; McCornick, P. Nephrotoxic contaminants in drinking water and urine, and chronic kidney disease in rural Sri Lanka. Sci. Total Environ. 2015, 518-519, 574-585. [CrossRef] [PubMed]

3. Wimalawansa, S.J. Escalating chronic kidney diseases of multi-factorial origin in Sri Lanka: Causes, solutions, and recommendations. Environ. Health Prev. Med. 2014, 19, 375-394. [CrossRef] [PubMed]

4. Chandrajith, R.; Dissanayake, C.B.; Ariyarathna, T.; Herath, H.M.J.M.K.; Padmasiri, J.P. Dose-dependent Na and $\mathrm{Ca}$ in fluoride-rich drinking water -Another major cause of chronic renal failure in tropical arid regions. Sci. Total Environ. 2011, 409, 671-675. [CrossRef]

5. Jayatilake, N.; Mendis, S.; Maheepala, P.; Mehta, F.R. Chronic kidney disease of uncertain aetiology: Prevalence and causative factors in a developing country. BMC Nephrol. 2013, 14, 180. [CrossRef]

6. Ranasinghe, H.; Ranasinghe, M. Status, Gaps and Way Forward in Addressing the Chronic Kidney Disease Unidentified (CKDu) in Sri Lanka. J. Environ. Prof. Sri Lanka 2015, 4, 58. [CrossRef]

7. Athuraliya, T.; Abeysekera, D.; Amerasinghe, P.; Kumarasiri, P.; Dissanayake, V. Prevalence of chronic kidney disease in two tertiary care hospitals: High proportion of cases with uncertain aetiology. Ceylon Med. J. 2009, 54, 23-25. [CrossRef]

8. World Health Organization (WHO). Chronic Kidney Disease of Unknown Origin (CKDu): National Research Programme for Chronic Kidney Disease of Unknown Origin (CKDu) in Sri Lanka; WHO: Geneva, Switzerland, 2013.

9. Dissanayake, C.B.; Chandrajith, R. Groundwater fluoride as a geochemical marker in the etiology of chronic kidney disease of unknown origin in Sri Lanka. Ceylon J. Sci. 2017, 46, 3. [CrossRef]

10. Wasana, H.M.S.; Aluthpatabendi, D.; Kularatne, W.M.T.D.; Wijekoon, P.; Weerasooriya, R.; Bandara, J. Drinking water quality and chronic kidney disease of unknown etiology (CKDu): Synergic effects of fluoride, cadmium and hardness of water. Environ. Geochem. Health 2016, 38, 157-168. [CrossRef]

11. Wickramarathna, S.; Balasooriya, S.; Diyabalanage, S.; Chandrajith, R. Tracing environmental aetiological factors of chronic kidney diseases in the dry zone of Sri Lanka-A hydrogeochemical and isotope approach. J. Trace Elem. Med. Biol. 2017, 44, 298-306. [CrossRef] 
12. Makehelwala, M.; Wei, Y.; Weragoda, S.K.; Weerasooriya, R.; Zheng, L. Characterization of dissolved organic carbon in shallow groundwater of chronic kidney disease affected regions in Sri Lanka. Sci. Total Environ. 2019, 660, 865-875. [CrossRef] [PubMed]

13. Brown, R.M.; McClelland, N.I.; Deininger, R.A.; O'Connor, M.F.A. Water Quality Index-Crashing the Psychological Barriers. In Proceedings of the Indicators of Environmental Quality-Proceedings of a symposium held during the AAAS meeting, Philadelphia, PA, USA, 26-31 December 1971; Thomas, W.A., Ed.; Plenum Press: New York, NY, USA, 1972.

14. Cooray, T.; Wei, Y.; Zhong, H.; Zheng, L.; Weragoda, S.K.; Weerasooriya, R. Assessment of groundwater quality in CKDu Affected areas of Sri Lanka: Implications for drinking water treatment. Int. J. Environ. Res. Public Health 2019, 16, 1698. [CrossRef] [PubMed]

15. Aumeier, B.M.; Yüce, S.; Wessling, M. Temperature Enhanced Backwash. Water Res. 2018, 142, $18-25$. [CrossRef] [PubMed]

16. Larsen, T.A.; Hoffmann, S.; Lüthi, C.; Truffer, B.; Maurer, M. Emerging solutions to the water challenges of an urbanizing world. Science 2016, 352, 928-933. [CrossRef] [PubMed]

17. Ray, C.; Jain, R. Low Cost Emergency Water Purification Technologies. Integrated Water Security Series, 1st ed.; Butterworth-Heinemann-Elsevier: Oxford, UK, 2014; ISBN 978-0-12-411465-4.

18. Mintz, E.D.; Reiff, F.M.; Tauxe, R.V. Safe Water Treatment and Storage in the Home. J. Am. Med. Assoc. 1995, 273, 948-953. [CrossRef]

19. Mohamed, H.; Clasen, T.; Njee, R.M.; Malebo, H.M.; Mbuligwe, S.; Brown, J. Microbiological effectiveness of household water treatment technologies under field use conditions in rural Tanzania. Trop. Med. Int. Health 2016, 21, 33-40. [CrossRef] [PubMed]

20. Pickering, A.J.; Arnold, B.F.; Dentz, H.; Colford, J.M.J.; Clasen, T.F.; Null, C. "lifestraw” water filters by rural kenyan households. In Proceedings of the 18th International Symposium on Health-related Water Microbiology, Lisboa, Portugal, 11-20 September 2015; Monteiro, S., Santos, R., Eds.; International Water Association: London, UK, 2015; p. 471.

21. Sobsey, M.D.; Stauber, C.E.; Casanova, L.M.; Brown, J.M.; Elliot, M.A. Point of use household drinking water filtration: A practical, effective solution for providing sustained access to safe drinking water in the developing world. Environ. Sci. Technol. 2008, 42, 4261-4267. [CrossRef]

22. Peter-varbanets, M.; Zurbru, C.; Swartz, C.; Pronk, W. Decentralized systems for potable water and the potential of membrane technology. Water Res. 2009, 43, 245-265. [CrossRef]

23. Aumeier, B.M.; Yüce, S.; Sheva, Y.; von Müller, G.; Vogt, G.; Wolf, A.; Vigneswaran, S.; Kazner, C. Report on Assessment, Pre-Selection, Recommendation of the Proposed Solutions for Development and Adaptation as Decentralised Water Treatment Solution for India; EU FP7 Project Water4India; European Commission: Luxembourg, 2014.

24. Schafer, A.I.; Fane, A.G.; Waite, T.D. Nanofiltration Principles and Applications, 1st ed.; Schafer, A.I., Fane, A.G., Waite, T.D., Eds.; Elsevier: Amsterdam, The Netherlands, 2005; ISBN 1-85617-405-3.

25. García-Vaquero, N.; Lee, E.; Jiménez Castañeda, R.; Cho, J.; López-Ramírez, J.A. Comparison of drinking water pollutant removal using a nanofiltration pilot plant powered by renewable energy and a conventional treatment facility. Desalination 2014, 347, 94-102. [CrossRef]

26. Richards, L.A.; Richards, B.S.; Schäfer, A.I. Renewable energy powered membrane technology: Salt and inorganic contaminant removal by nanofiltration/reverse osmosis. J. Membr. Sci. 2011, 369, 188-195. [CrossRef]

27. Wang, J.; Li, K.; Yu, D.; Zhang, J.; Wei, Y. Fouling characteristics and cleaning strategies of NF membranes for the advanced treatment of antibiotic production wastewater. Environ. Sci. Pollut. Res. 2017, 24, 8967-8977. [CrossRef] [PubMed]

28. Gao, F.; Wang, J.; Zhang, H.; Zhang, Y.; Hang, M.A. Effects of sodium hypochlorite on structural/surface characteristics, filtration performance and fouling behaviors of PVDF membranes. J. Membr. Sci. 2016, 519, 22-31. [CrossRef]

29. HYDRANAUTICS- Nitto Group Company. Chemical Pretreatment for RO and NF. Technical Application Bulletin No. 111; HYDRANAUTICS- Nitto Group Company: Oceanside, CA, USA, 2013.

30. Stoquart, C.; Servais, P.; Bérubé, P.R.; Barbeau, B. Hybrid Membrane Processes using activated carbon treatment for drinking water: A review. J. Membr. Sci. 2012, 411-412, 1-12. [CrossRef] 
31. Miao, R.; Li, X.; Wu, Y.; Wang, P.; Wang, L.; Wu, G.; Wang, J.; Lv, Y.; Liu, T. A comparison of the roles of Ca ${ }^{2+}$ and $\mathrm{Mg}^{2+}$ on membrane fouling with humic acid: Are there any differences or similarities? J. Membr. Sci. 2018, 545, 81-87. [CrossRef]

32. Matsuno, Y.; Elkaduwa, W.K.B.; Shinogi, Y. Irrigation water quality in the southeastern dry zone of Sri Lanka. The Kirindi Oya Scheme. In Status and Future Direction of Water Research in Sri Lanka, Proceedings of the National Conference held at the BMICH, Colombo, Sri Lanka, 4-6 November 1998; Samad, M., Wijesekera, N.T.S., Birch, A., Eds.; International Water Management Institute (IWMI): Colombo, Sri Lanka, 2000; pp. 89-100.

33. Government of Sri Lanka. Gazette Extraordinary of the Democratic Socialist Rpublic of Sri Lanka-2008-02-01 Tolerance Limits for Discharge of Industrial Waste Water; Government of Sri Lanka: Colombo, Sri Lanka, 2008.

34. Sri Lanka Standards Institution. Sri Lanka Standard Institution: Specification for Potable Water-(First Revision); Sri Lanka Standards Institution: Colombo, Sri Lanka, 2013.

35. Paul, D.H. The Four Most Common Problems in Membrane Water Treatment Today; David H. Paul, Inc.: Graham, NC, USA, 2014.

36. Muthukumarana, N.N.; Premachandra, N.P.; Ritigala, H.M.T.S. Analysis of Water Quality Parameters in Reverse Osmosis Treated Water in Chronic Kidney Disease of Unknown Etiology (CKDu) Affected Areas. In Proceedings of the International Symposium-Uva Wellassa University, Badulla, Sri Lanka, 20-21 January 2017; Uva Wellassa University Sri Lanka: Badulla, Sri Lanka, 2017; p. 318.

37. Colliver, B.B.; Stephenson, T. Production of nitrogen oxide and dinitrogen oxide by autotrophic nitrifiers. Biotechnol. Adv. 2000, 18, 219-232. [CrossRef]

38. Iyer, K.; Gajalakshmi, S.; Mythili, S.; Sathiavelu, A. Microbial BioRemediation-A Review. J. Agric. Vet. Sci. 2012, 4, 4-13.

39. Mermod, M.; Solioz, M.; Abicht, H.K.; Atpases, C.; Mancini, S. Response of Gram-positive bacteria to copper stress. J. Biol. Inorg. Chem. 2010, 15, 3-14.

40. Inglis, R.F.; Scanlan, P.; Buckling, A. Iron availability shapes the evolution of bacteriocin resistance in Pseudomonas aeruginosa. ISME J. 2016, 10, 2060-2066. [CrossRef]

41. Douterelo, I.; Fish, K.E.; Boxall, J.B. Succession of bacterial and fungal communities within biofilms of a chlorinated drinking water distribution system. Water Res. 2018, 141, 74-85. [CrossRef]

42. Lv, L.; Jiang, T.; Zhang, S.; Yu, X. Exposure to mutagenic disinfection by-products leads to increase of antibiotic resistance in Pseudomonas aeruginosa. Environ. Sci. Technol. 2014, 48, 8188-8195. [CrossRef]

43. Chen, L.; Zheng, D.; Liu, B.; Yang, J.; Jin, Q. VFDB 2016: hierarchical and refined dataset for big data analysis-10 years on. Nucleic Acids Res. 2016, 44, D694-D697. [CrossRef] [PubMed]

44. Bouskill, N.J.; Barnhart, E.P.; Galloway, T.S.; Handy, R.D.; Ford, T.E. Quantification of changing Pseudomonas aeruginosa sodA, htpX and $\mathrm{mt}$ gene abundance in response to trace metal toxicity: A potential in situ biomarker of environmental health. FEMS Microbiol. Ecol. 2007, 60, 276-286. [CrossRef] [PubMed]

(C) 2019 by the authors. Licensee MDPI, Basel, Switzerland. This article is an open access article distributed under the terms and conditions of the Creative Commons Attribution (CC BY) license (http://creativecommons.org/licenses/by/4.0/). 